\title{
TASK ROUTINENESS AND TRADE POLICY PREFERENCES
}

\author{
Bruce A. Blonigen* AND JaCOB MCGREW
}

\begin{abstract}
Understanding the formation of individual trade policy preferences is a fundamental input into the modeling of trade policy outcomes. Surprisingly, past studies have found mixed evidence that various labor market and industry attributes of workers affect their trade policy preferences, even though recent studies have found that trade policy can have substantial impacts on workers' incomes. This paper provides the first analysis of the extent to which task routineness affects trade policy preferences using survey data from the American National Election Studies. We find significant evidence that greater task routineness leads workers to be much more supportive of import restrictions, consistent with recent evidence on how trade openness puts downward pressure on employment and wages for workers whose occupations involve routine tasks. In fact, other than education levels, task routineness is the only labor market attribute that displays a robust correlation with individuals' stated trade policy preferences. We also provide evidence that there are some interactions between the economic and non-economic factors in our study. For example, women's trade policy views are much more invariant to their labor market attributes than men, suggesting that women's views on this issue are driven more by personal and ideological beliefs than men.
\end{abstract}

\section{INTRODUCTION}

Understanding how people form opinions about policies on international economic relations, such as international trade, is a fundamental question for not only scholars but also policy makers. Economists typically begin with the premise that individuals' preferences for international economics policies (typically, regarding international trade or immigration) are determined by how these international phenomena affect individuals' employment and wage outcomes. However, non-economic factors, such as political ideology, may also play a large factor in people's opinions on international policies. (O'Rourke and Sinnott, 2001)

In the economics literature, researchers have relied on either the Heckscher-Ohlin (H-O) framework or the alternative sector-specific model to motivate predictions about how trade will affect individual workers' real wages and, hence, their view on trade policy. In the standard $\mathrm{H}-\mathrm{O}$ setup, workers are mobile across sectors and so their income depends on their labor endowments and skills, not their current sector of employment. Assuming that income effects from trade are the main driver of trade preferences for an individual, workers with less skills residing in a skill-abundant country will be subject to declines in the probability of employment and real income due to freer trade (see, e.g., Autor et al., 2006; Ebenstein et al., forthcoming; Hummels et al., 2014). Consequently, these less-skilled workers will favor trade protection in skill-abundant countries, and vice versa.

Alternatively, workers are "stuck" in their sector, as in a sector-specific factors model. Now workers of all skill levels in a sector are similarly affected by the sector's

\footnotetext{
*Corresponding author: Bruce A. Blonigen, Department of Economics, 1285 University of Oregon, Eugene, OR 97403, USA. E-mail: bruceb@uoregon.edu
} 
exposure to international trade. In this setting, it is only the sector's (or industry's) particular exposure to international trade that affects workers' wages, not their relative skills.

Past empirical analyses using data on lobbyist positions on trade, as well as on votes by elected representatives, largely conclude that industry characteristics, and not human capital endowments (proxies for personal skills), determine trade policies. These studies are likely capturing determinants of lobbying inputs, so it is not surprising that human capital endowment measures do not hold much support. More recent analyses of the political economy of trade protection by Mayda and Rodrik (2005), O'Rourke and Sinnott (2001), and Scheve and Slaughter (2001) use survey data on individuals' stated preferences for trade policies. These studies find support for both workers' skill levels and industry characteristics as determinants of individuals' support for trade protection.

However, there are a number of reasons why there may be a need to revisit and reassess the literature. First, there have been recent concerns with the robustness of these results (see Blonigen, 2011), calling into question that labor market outcomes affect individuals' trade policy views. Second, and relatedly, when these studies have also included non-economic (what we will call personal and ideological attributes), the evidence and magnitude of these non-economic factors are often much more substantial than the economic forces (e.g., see Mayda and Rodrik, 2005; O'Rourke and Sinnott, 2001). For example, studies have a found a very strong and large gender difference, with women 8-10 percentage point more likely to favor trade protection than men, all else equal. A final reason to reassess is the recent literature suggesting the possibility that our traditional proxies for skill (such as education attainment) are far from ideal in measuring the exposure of workers to the effects of globalization. In particular, Autor et al. (2003) introduce a new perspective on worker's skills and their vulnerability to international markets by distinguishing "routine" tasks, which can be well described by deductive rules, from "non-routine" tasks, which require pattern recognition and inductive reasoning. This insight has generated a recent empirical literature showing that greater international market exposure (such as offshoring) can significantly affect wages of workers according to the routineness of the tasks required for their position. For example, Ebenstein et al. (forthcoming) and Hummels et al. (2014) show that offshoring has negative effects on workers whose jobs involve routine tasks, and positive effects for workers whose jobs require non-routine tasks. The latter effect is consistent with offshoring bringing productivity gains for the firms, leading to wage gains for the remaining non-routine workers. ${ }^{1}$ Ebenstein et al. (forthcoming) show that offshoring has substantial impacts at the occupational level (particularly negative effects for those in occupations that perform a high amount of routine tasks) within industries, not on wage differentials across industries.

Importantly, task routineness is specific to one's occupation and not necessarily correlated with the typical measures of workers' skills, such as those proxied by education levels. There are a number of examples of jobs that require advanced education, but have significant "routineness" to the tasks they do (e.g., positions in computer programming, x-ray technician positions, legal services). The correlations between years of education and measures of routineness found in Autor et al. (2003) are 0.46 for

\footnotetext{
${ }^{1}$ This effect is predicted in the model of "trading tasks" developed in Grossman and Rossi-Hansberg (2008).
} 
non-routine analytical (i.e., general educational development, mathematics), 0.36 for non-routine interactive (i.e., direction, control, and planning), -0.14 for routine cognitive (i.e., limits, tolerances, or standards), 0.03 for routine manual (i.e., finger dexterity), and -0.06 for non-routine manual (i.e., eye, hand, and foot coordination). ${ }^{2}$ Despite the strong evidence that task routineness of one's occupation can affect how international market openness can affect one's wage income and differs from our normal measures for "skilled" labor, no one has yet examined whether task routineness affects people's stated trade policy preferences.

In this paper, we examine this issue for the first time by using survey evidence on United States individuals' attitudes toward trade protection between 1986 and 2000. Like Blonigen (2011) and Scheve and Slaughter (2001), we use data on individuals' responses to a question posed by the American National Election Studies (ANES) about whether the United States should increase import restrictions. The ANES surveys provide much more detailed data on individual characteristics compared to other surveys used in the literature. In addition to examining how factors such as worker skills or industry trade characteristics affect workers' attitudes, as in previous studies, we also examine how these workers' attitudes differ depending on the routineness of tasks performed in one's occupation. We follow the recent literature in using information on the routineness of tasks from the dataset used in Autor et al. (2003), as well as an alternative summary measure of task routineness used by Ebenstein et al. (forthcoming).

We find evidence that task routineness is a significant independent factor in individuals' opinions about trade policies. In particular, a standard deviation increase in the routineness of tasks in one's occupation is associated with a 3-percentage point increase in the likelihood that an individual will favor new import limits. This is consistent with the findings by prior studies that increased trade openness will put pressure on wages of workers in occupations that have greater task routineness. Notably, our estimates of the task routineness effect on trade policy preferences are robust to including other (standard) measures of labor market attributes, such as the education of the worker and the net export share of the worker's sector. It is also robust to including a full set of personal and ideological attributes, including gender and political affiliation, which have been found to be strong predictors of trade policy preferences in previous studies. In fact, other than education levels, task routineness is the only labor market attribute that displays a robust correlation with individuals' stated trade policy preferences.

We also examine for the first time how the effect of labor market attributes may vary with personal and ideological attributes, such as gender and political affiliation. We find that women's trade policy preferences do not vary as much with their labor market attributes as men. For example, an extra year of education does not lower women's likelihood to support additional import limits as much as it does for men. We also find some differences in trade policy elasticities with respect to labor market attributes across a number of other dimensions, including political party and union affiliation. Unlike with gender differences, these differences in other dimensions are driven by nonlinear elasticities of trade policy preferences to labor market attributes. For example, we find that the trade policy preferences of

\footnotetext{
${ }^{2}$ Many studies have used production vs. non-production workers (e.g., Feenstra and Hanson, 1999), which are likely even less correlated with task attributes of one's position, such as routineness.
} 
workers in manufacturing sectors are more affected by routineness due to the fact that the average routineness of tasks is generally much higher in manufacturing than in other sectors.

The remainder of our paper proceeds as follows. The next section provides a discussion of the ANES survey data and task routineness data we use, as well as the base empirical specification. Section 3 presents the paper's empirical results, and section 4 concludes.

\title{
2. EMPIRICAL SPECIFICATION AND DATA
}

From the ANES surveys, we create a dataset that includes survey years 1986, 1988, 1992, 1996, and $1998 .^{3}$ In the survey, the ANES asks the following question:

\begin{abstract}
"Some people have suggested placing new limits on foreign imports in order to protect American jobs. Others say that such limits would raise consumer prices and hurt American exports. Do you favor or oppose placing new limits on imports, or haven't you thought much about this?"
\end{abstract}

We construct a dependent variable that assigns a " 1 " when the individual responds that they favor new limits on imports, and a " 0 " when they oppose new limits. 4 Following past studies, we estimate a reduced-form specification of the dependent variable as a linear function of the covariates. We estimate this specification using the ordinary least squares (OLS) method, as it gives the most ease and flexibility to modify the specification and interpret marginal effects. However, given the binary nature of our dependent variable, we have also estimated with a logit specification and note that it yields qualitatively identical results as OLS throughout our analysis.

Key covariates and base specification follow directly from Blonigen (2011) and Scheve and Slaughter (2001), using two alternative measures of an individual's skill and two alternative measures of trade exposure of the industry in which the individual works. The measures of skill are Education Years and Relative Occupation Wage, while the two measures of industry trade exposure are Sector Tariff and Sector Net Export Share of output (or sales) for a survey respondent's industry of employment. We expect a positive correlation between tariffs in an individual's employment industry and their preference for import protection, and a negative correlation between their employment industry's net export share and their preference for import protection.

Because homes are often an important asset for individuals and home values depend on economic activity in the immediate location, a secondary focus of Scheve and Slaughter (2001) is looking at whether homeowners in trade-sensitive locations will be more likely to prefer trade protections - denoted by a dependent variable for County Trade Exposure, as well as an interaction variable for whether the individual taking the survey is a homeowner or not. We control for these variables as well, and include

\footnotetext{
${ }^{3}$ These are the only years that are usable for our purposes. In 1990, the ANES survey asked respondents to rank their preferences for new import limits over a range from 1 to 7, where it is not obvious on how to correspond these responses into a binary variable in an analogous fashion to the other survey years. We also exclude the year 2000 - the final year the question was asked - because individuals' county of residence is not reported in that year's survey, which is needed for some our control variables. See Blonigen (2011) for more details.

${ }^{4}$ This excludes individuals who respond that they have not thought much about the issue. Blonigen (2011) and Scheve and Slaughter (2001) find that empirical estimates are qualitatively very similar when one includes these individuals and employs a sample selection correction.
} 
other personal and ideological characteristics in our regression specifications, including age, gender, race, political party affiliation, union membership, and household income levels. These data come directly from the ANES survey questions and were included in Blonigen (2011), which describes the construction of all these independent variables in more detail. Unlike the previous studies, we limit our sample to only those currently in the work force or looking for work. Not surprisingly, this tends to strengthen the influence of the labor market characteristics on individuals' trade policy preferences.

Our particular focus in this paper is to examine whether task routineness of a workers' occupation affects their trade policy preferences. We use the dataset developed by Autor et al. (2003), which extracts five measures of occupation task attributes from the U.S. Department of Labor's Dictionary of Occupational Titles: 1) Setting limits, tolerances, or standards (Routine Cognitive); 2) finger dexterity (Routine Manual); 3) mathematics (Non-routine Analytic); 4) direction, control, and planning of activities (Non-routine Interactive), and 5) eye, hand, and food coordination (Non-routine Manual). ${ }^{5}$ We also examine a more summarized measure of routineness variable examined by Autor et al. (2003) and Ebenstein et al. (forthcoming), which we label Routineness and calculate using the weighted average:

$$
\begin{aligned}
\text { Routineness }= & (\text { Routine Cognitive }+ \text { Routine Manual }) /(\text { Routine Cognitive } \\
& + \text { Routine Manual }+ \text { Non }- \text { routine Interactive } \\
& + \text { Non }- \text { routine Manual }+ \text { Non }- \text { routine Analytic }) .
\end{aligned}
$$

We concord these data at the 2-digit census occupation code of the individual collected in the ANES surveys. There are 70 different 2-digit census occupation codes, ranging from "Extractive Occupations" to "Clerical Supervisors."

Table 1 provides summary statistics of all the variables used in this study's analysis. About $61 \%$ of the 4,355 individuals in the sample support additional new import limits. The average individual in the sample has about 1.5 years of school beyond high school and is around 41 years old. About $35 \%$ indicate that their political party is Democrat, while $29 \%$ indicate they are Republicans. Around $66 \%$ own their house, $21 \%$ have at least one member in the household who belongs to a labor union and, because of our focus on those in the work force, about $62 \%$ in the sample are male.

Table 2 provides a matrix of pairwise correlations between the various measures of an individual's labor market attributes that we will explore in our analysis below. These include the industry characteristics (Sector Tariff and Sector Net Export Share) and skills characteristics (Relative Wages and Education) employed by previous studies, as well as the measures of task routineness that we are introducing to this literature. Of the 45 correlations, only nine have correlations above 0.5 in absolute value and none has a correlation greater than 0.75 . This suggests that these various measures are often capturing different aspects of an individual's labor market attributes. The task routineness measures have generally even lower pairwise correlations with the industry and skills variables, indicating that task routineness may provide additional information for explaining individuals' trade policy preferences.

\footnotetext{
${ }^{5}$ These data can be accessed at a data archive webpage maintained by David Autor: http://economics.mit. edu/faculty/dautor/data.

${ }^{6} \mathrm{We}$ do not include data on codes 71 (Military) or 99 (NA) since military occupations are not able to be offshored. Our statistical results are unaffected whether we include workers in these categories or not.
} 
Table 1 Summary Statistics

\begin{tabular}{|c|c|c|c|c|}
\hline Variables & Mean & S.D. & Minimum & Maximum \\
\hline \multicolumn{5}{|l|}{ Dependent variable } \\
\hline Supports additional import limits & 0.61 & 0.49 & 0.00 & 1.00 \\
\hline \multicolumn{5}{|l|}{ Independent variables } \\
\hline \multicolumn{5}{|l|}{ Individual skills } \\
\hline Relative occupation wage & 1.14 & 0.33 & 0.36 & 1.60 \\
\hline Education years & 13.58 & 2.49 & 1.00 & 17.00 \\
\hline \multicolumn{5}{|l|}{ Sector trade exposure } \\
\hline Sector tariff & 0.01 & 0.02 & 0.00 & 0.27 \\
\hline Sector net export share & 0.00 & 0.10 & -1.65 & 0.53 \\
\hline Own house & 0.66 & 0.47 & 0.00 & 1.00 \\
\hline Country trade exposure & 0.06 & 0.06 & 0.00 & 0.44 \\
\hline Country trade exposure $\times$ own house & 0.04 & 0.06 & 0.00 & 0.44 \\
\hline \multicolumn{5}{|l|}{ Task routineness measures } \\
\hline Routine cognitive & 3.34 & 3.37 & 0.00 & 10.00 \\
\hline Routine manual & 3.69 & 1.15 & 0.37 & 8.99 \\
\hline Non-routine analytic & 2.97 & 3.53 & 0.00 & 9.60 \\
\hline Non-routine interactive & 1.44 & 1.55 & 0.00 & 10.00 \\
\hline Non-routine manual & 3.68 & 1.95 & 0.00 & 10.00 \\
\hline Routineness & 0.48 & 0.22 & 0.03 & 0.90 \\
\hline \multicolumn{5}{|l|}{ Other controls } \\
\hline Age (in years) & 40.76 & 12.64 & 18.00 & 72.00 \\
\hline Women & 0.38 & 0.49 & 0.00 & 1.00 \\
\hline African American & 0.09 & 0.29 & 0.00 & 1.00 \\
\hline Asian American & 0.02 & 0.14 & 0.00 & 1.00 \\
\hline Hispanic & 0.06 & 0.24 & 0.00 & 1.00 \\
\hline Native American & 0.04 & 0.20 & 0.00 & 1.00 \\
\hline Democrat & 0.35 & 0.48 & 0.00 & 1.00 \\
\hline Republican & 0.29 & 0.45 & 0.00 & 1.00 \\
\hline Union membership in household & 0.21 & 0.41 & 0.00 & 1.00 \\
\hline Household income - first (lowest) quartile & 0.15 & 0.36 & 0.00 & 1.00 \\
\hline Household income - second quartile & 0.23 & 0.42 & 0.00 & 1.00 \\
\hline Household income - third quartile & 0.27 & 0.44 & 0.00 & 1.00 \\
\hline
\end{tabular}

\section{EMPIRICAL RESULTS}

Our base OLS results are presented in Table 3. The first column of Table 3 presents a specification that follows past literature and does not include any measures of task routineness. Of the 19 covariates, only seven of them are statistically significant at the $10 \%$ significance level or better. Of the labor market attribute variables, education is statistically significant at the $1 \%$ level and its coefficient indicates that each additional year of schooling lowers the likelihood that an individual will support additional import limits by 3.8 percentage points. This fits with the hypothesis that skilled workers' wages gain from open trade in a country, such as the United States, that has comparative advantage in skill-intensive goods. The only other labor market attribute to have some statistical significance is the tariff in the individual's sector, with a positive coefficient indicating that workers' in more protected industries favor additional import limits. A standard deviation increase in a sector's tariff $(0.02)$ means the individual's likelihood of supporting additional import limits by 0.9 percentage points - a fairly small marginal effect. The statistical significance of this variable is also not robust to alternative specifications, as seen in the other columns of Table 3. 


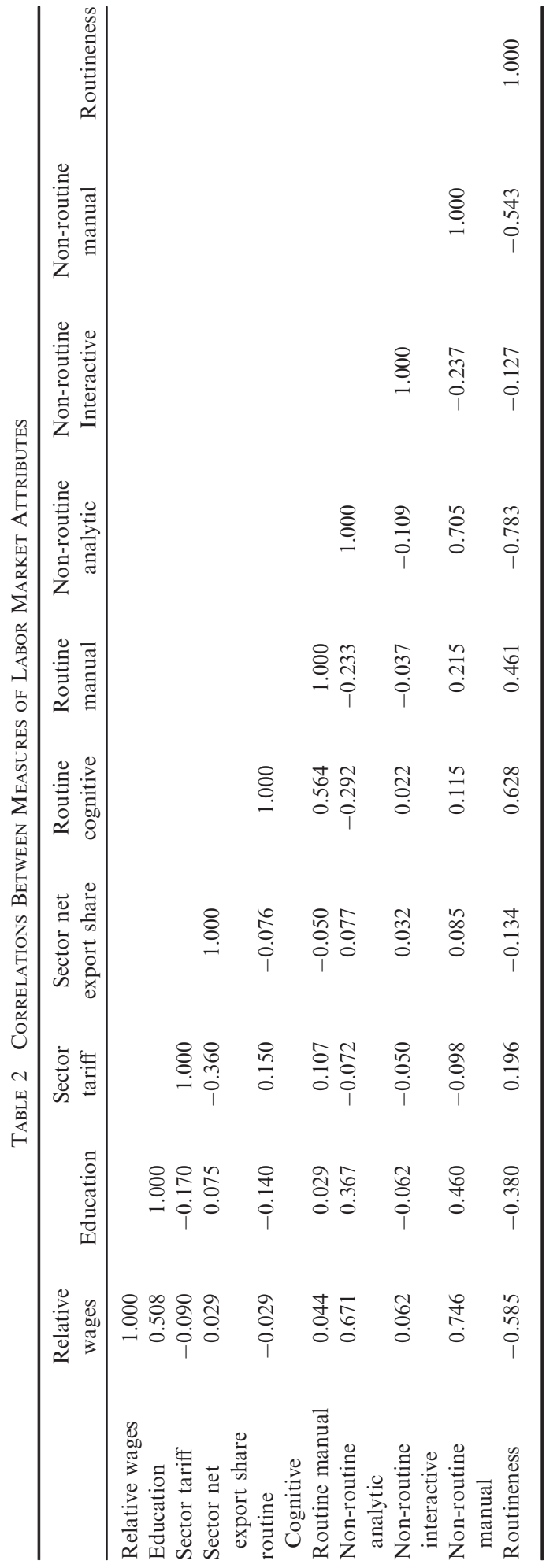


Table 3 Effects of Labor Market Attributes on Support for Additional Import Limits

\begin{tabular}{|c|c|c|c|}
\hline Variables & Base & Autor et al. measures & Routineness measure \\
\hline \multicolumn{4}{|l|}{ Individual skills } \\
\hline Relative occupation wage & $\begin{array}{c}0.004 \\
(0.025)\end{array}$ & $\begin{array}{l}0.132 * * * \\
(0.038)\end{array}$ & $\begin{array}{c}0.051^{*} \\
(0.029)\end{array}$ \\
\hline Education years & $\begin{array}{c}-0.038 * * * \\
(0.003)\end{array}$ & $\begin{array}{c}-0.035^{* * *} \\
(0.004)\end{array}$ & $\begin{array}{l}-0.037 * * * \\
(0.004)\end{array}$ \\
\hline \multicolumn{4}{|l|}{ Sector trade exposure } \\
\hline Sector tariff & $\begin{array}{c}0.451^{*} \\
(0.264)\end{array}$ & $\begin{array}{c}0.372 \\
(0.269)\end{array}$ & $\begin{array}{c}0.370 \\
(0.265)\end{array}$ \\
\hline Sector net export share & $\begin{array}{r}-0.077 \\
(0.069)\end{array}$ & $\begin{array}{r}-0.037 \\
(0.069)\end{array}$ & $\begin{array}{r}-0.057 \\
(0.069)\end{array}$ \\
\hline Own house & $\begin{array}{c}0.036^{*} \\
(0.022)\end{array}$ & $\begin{array}{c}0.037^{*} \\
(0.022)\end{array}$ & $\begin{array}{c}0.038 * \\
(0.022)\end{array}$ \\
\hline Country trade exposure & $\begin{array}{c}0.166 \\
(0.192)\end{array}$ & $\begin{array}{c}0.140 \\
(0.191)\end{array}$ & $\begin{array}{c}0.156 \\
(0.192)\end{array}$ \\
\hline Country trade exposure $\times$ own house & $\begin{array}{c}0.004 \\
(0.227)\end{array}$ & $\begin{array}{c}0.018 \\
(0.227)\end{array}$ & $\begin{array}{c}0.002 \\
(0.227)\end{array}$ \\
\hline \multicolumn{4}{|l|}{ Task routineness measures } \\
\hline Routine cognitive & & $\begin{array}{l}0.007 * * \\
(0.003)\end{array}$ & \\
\hline Routine manual & & $\begin{array}{c}0.004 \\
(0.008)\end{array}$ & \\
\hline Non-routine analytic & & $\begin{array}{c}-0.000 \\
(0.004)\end{array}$ & \\
\hline Non-routine interactive & & $\begin{array}{c}-0.015 * * * \\
(0.005)\end{array}$ & \\
\hline Non-routine manual & & $\begin{array}{l}-0.031 * * * \\
(0.008)\end{array}$ & \\
\hline Routineness measure & & & $\begin{array}{l}0.137 * * * \\
(0.041)\end{array}$ \\
\hline \multicolumn{4}{|l|}{ Other controls } \\
\hline Age (in years) & $\begin{array}{c}0.000 \\
(0.001)\end{array}$ & $\begin{array}{c}0.000 \\
(0.001)\end{array}$ & $\begin{array}{c}0.000 \\
(0.001)\end{array}$ \\
\hline Women & $\begin{array}{l}0.076^{* * * *} \\
(0.015)\end{array}$ & $\begin{array}{l}0.077 * * * \\
(0.016)\end{array}$ & $\begin{array}{l}0.078^{* * *} \\
(0.015)\end{array}$ \\
\hline African American & $\begin{array}{c}0.031 \\
(0.025)\end{array}$ & $\begin{array}{c}0.028 \\
(0.025)\end{array}$ & $\begin{array}{c}0.030 \\
(0.025)\end{array}$ \\
\hline Asian American & $\begin{array}{r}-0.017 \\
(0.057)\end{array}$ & $\begin{array}{r}-0.019 \\
(0.057)\end{array}$ & $\begin{array}{r}-0.021 \\
(0.057)\end{array}$ \\
\hline Hispanic & $\begin{array}{c}-0.039 \\
(0.030)\end{array}$ & $\begin{array}{c}-0.042 \\
(0.030)\end{array}$ & $\begin{array}{r}-0.040 \\
(0.030)\end{array}$ \\
\hline Native American & $\begin{array}{c}0.022 \\
(0.036)\end{array}$ & $\begin{array}{c}0.025 \\
(0.035)\end{array}$ & $\begin{array}{c}0.024 \\
(0.036)\end{array}$ \\
\hline Democrat & $\begin{array}{l}0.044 * * * \\
(0.015)\end{array}$ & $\begin{array}{l}0.045^{* * *} \\
(0.015)\end{array}$ & $\begin{array}{l}0.045^{* * * *} \\
(0.015)\end{array}$ \\
\hline Republican & $\begin{array}{c}0.009 \\
(0.015)\end{array}$ & $\begin{array}{c}0.009 \\
(0.015)\end{array}$ & $\begin{array}{c}0.010 \\
(0.015)\end{array}$ \\
\hline Union membership in household & $\begin{array}{l}0.102 * * * \\
(0.017)\end{array}$ & $\begin{array}{l}0.087 * * * \\
(0.018)\end{array}$ & $\begin{array}{l}0.096^{* * *} \\
(0.017)\end{array}$ \\
\hline Household income - first (lowest) quartile & $\begin{array}{c}0.025 \\
(0.025)\end{array}$ & $\begin{array}{c}0.022 \\
(0.025)\end{array}$ & $\begin{array}{c}0.025 \\
(0.025)\end{array}$ \\
\hline Household income - second quartile & $\begin{array}{l}0.065^{*} * * \\
(0.020)\end{array}$ & $\begin{array}{l}0.058 * * * \\
(0.020)\end{array}$ & $\begin{array}{l}0.062^{* * *} \\
(0.020)\end{array}$ \\
\hline
\end{tabular}


TABLE 3 (continued)

\begin{tabular}{lccc}
\hline Variables & Base & Autor et al. measures & Routineness measure \\
\hline Household income - third quartile & 0.025 & 0.021 & 0.023 \\
& $(0.018)$ & $(0.018)$ & $(0.018)$ \\
$R^{2}$ & 0.12 & 0.12 & 0.12 \\
$F$-statistic ( $p$-Value) & 29.11 & 25.72 & 28.75 \\
Number of observations & $(0.000)$ & $(0.000)$ & $(0.000)$ \\
\hline
\end{tabular}

Notes: Dependent variable takes the value of " 1 " if the individual expresses support for additional import limits, and a " 0 " otherwise. All regressions include year fixed effects. ***, **, and * denote statistical significance at the $1 \%, 5 \%$, and $10 \%$ levels, respectively. Robust standard errors in parentheses.

A number of ideological/personal attributes of an individual have robust and strong effects on trade policy preferences in our base results in column 1 . Women are much more likely to support new import limits than men by almost 8 percentage points. This is consistent with findings by other studies, including Beaulieu and Napier (2008), Blonigen (2011), Burgoon and Hiscox (2004), Mayda and Rodrik (2005), and O'Rourke and Sinnott (2001). Affiliation with the Democratic Party increases the likelihood of an individual's support for additional import limits by about 4.5 percentage points relative to independent and Republican voters, while union membership by someone in the individual's household increases the likelihood of support by over 10 percentage points. Interestingly, there are also household income effects even while controlling for labor market attributes of the individual (including the individual's wage). The likelihood that an individual whose household income is in the second lowest income quartile supports additional import limits is 6.5 percentage points higher than an individual whose household income is in the highest quartile (the excluded group). In unreported results, we find that this income effect is statistically significant and similar in magnitude for individuals in both the lowest and second quartile groups when we include individuals in the sample who are not in the work force. Thus, lower income is associated with more support for trade protection, even after controlling labor market attributes, which is surprising and not accounted for in our standard trade theories. ${ }^{7}$

In summary, our base results are consistent with the previous literature in finding only modest support for the effect of labor market attributes on individuals' trade policy preferences, while finding strong support for a number of personal/ideological attributes of the person, including gender, household income, political party, and union affiliation. Interestingly, there is still much heterogeneity in trade policy preferences remaining to be explained, as the $R^{2}$ statistic for the regression is just 0.12 .

The main focus of this paper is to examine the effect of including measures of task routineness, which may be labor market attributes that are more related to how trade openness affects individuals' labor market outcomes and, hence, their support or opposition to more open trade. Column 2 of Table 3 provides estimates when we include the five measures of task routineness used by Autor et al. (2003), while column

\footnotetext{
${ }^{7}$ This point is also made by Mayda and Rodrik (2005), which finds a similar income effect on support for trade protection.
} 
3 of Table 3 instead includes the summary measure of routineness used by others, including Ebenstein et al. (forthcoming).

The measures of task routineness come in with expected signs, with greater task routineness associated with increased support for additional import limits, and the opposite sign for measures of task non-routineness. Most of these task routineness measures are also statistically and economically significant. Three of the five Autor et al. (2003) variables are statistically significant at the 5\% level and the summary measure (Routineness) in column 3 is statistically significant at the $1 \%$ level. The economic magnitudes are reasonably significant as well, with a standard deviation leading to a 2-6 percentage point difference in the individual's likelihood of supporting additional import limits among the Autor et al. (2003) measures, and a 3 percentage point increase in the likelihood of support for additional import limits for a standard deviation increase in the summary measure, Routineness, in the column 3 estimates.

In summary, there is substantial evidence that task routineness is important for understanding individuals' trade policy preferences independent of their other labor market attributes. Interestingly, inclusion of the task routineness measures has almost no impact on the sign and significance of the other included covariates. Education of an individual continues to be an important determinant, as do the previously discussed personal/ideological variables. In addition, the $R^{2}$ statistic of the estimated equation when including the task routineness measures does not noticeably increase, remaining at 0.12 when rounded to the second digit. Thus, while there is support that task routineness measures are important, they do not provide a significant change in the explanatory power of the covariate matrix.

\subsection{Labor Market Attributes Along Personal/Ideological Dimensions}

Given the strong effect of a number of key personal/ideological attributes, an interesting question is the extent to which the effects of labor market attributes on trade policy preferences differ across these dimensions. Surprisingly, this has not been previously explored in the literature to our knowledge. In this section, we estimate differences in labor market attribute effects across a number of dimensions, including gender, political affiliation, and union affiliation.

Table 4 provides separate estimates of the effect of labor market attributes on trade policy preferences for men and women in the sample, respectively. ${ }^{8}$ We use the same specification as column 3 of Table 3, but only report the coefficient estimates for the labor market attributes. The general pattern in these estimates is that labor market attributes have less effect on trade policy preferences of women. Each year of education reduces a man's likelihood of support for additional import limits by 3.9 percentage points, whereas it only reduces a woman's likelihood of support by 3.0 percentage points. (The $F$-statistic in column 3 of Table 4 shows that this difference is statistically significant at the 1\% level). In addition, Sector Net Export Share has a significant negative coefficient (as expected) for men, but is insignificant for women. Likewise, the effect of task routineness on support for additional import limits is strongly significant for men, but has a coefficient that is less than half as large and is insignificant for the sample of women. The effect of Relative Wages and Sector Tariff on trade policy

\footnotetext{
${ }^{8} \mathrm{We}$ estimate these separate effects using the full sample of observations and including a full set of interactions of the Women variable with all other covariates in the specification.
} 
Table 4 Labor Market Attributes Have Less Effect on Women’s Preferences for New Import LIMITS

\begin{tabular}{lccc}
\hline Variables & Men & Women & F-test for difference \\
\hline Individual skills & & & \\
Relative occupation wage & 0.050 & $\left(0.031^{*}\right.$ & 0.70 \\
& $-0.039^{* * *}$ & $-0.030^{* * *}$ & $35.41^{* * *}$ \\
Education years & $(0.000)$ & $(0.000)$ & \\
Sector trade exposure & 0.518 & $0.552^{*}$ & 0.28 \\
Sector tariff & $(0.229)$ & $(0.093)$ & $3.91^{* *}$ \\
Sector net export share & $-0.181^{*}$ & 0.059 & \\
& $(0.053)$ & $(0.564)$ & $6.81^{* * *}$ \\
Task routineness measure & $0.169^{* * *}$ & 0.070 & \\
Routineness measure & $(0.001)$ & $(0.240)$ & \\
&
\end{tabular}

Notes: Dependent variable takes the value of "1" if the individual expresses support for additional import limits, and a "0" otherwise. All regressions include year fixed effects and other controls listed in Table 3. $* * *, * *$, and $*$ denote statistical significance at the $1 \%, 5 \%$, and $10 \%$ levels, respectively. $p$-Values in parentheses.

preferences is the same across the two samples, but both effects are only marginally significant. The effect of Sector Tariff is relatively small, with a standard deviation increase meaning about a 1.0 percentage point change in the likelihood of support for additional import limits. These results suggest that women's trade policy preferences are driven by personal ideology on this issue rather than their own labor market attributes.

Democratic Party and union affiliation are two other personal/ideological attributes that have strong independent effects on trade policy preferences in our estimates, so we also examine how these two attributes interact with the labor market attributes. Table 5 examines whether labor market attributes have different impacts on trade policy preferences for Democrats vs. other party affiliations (Republicans and independents), while Table 6 does the same for union vs. non-union households.

As with women, Democrats' trade policy preferences are less affected by traditional labor market attributes. An extra year of education reduces a Democrat's likelihood of support by only 3.3 percentage points vs. 3.9 percentage points for individuals of other political affiliations. In addition, Sector Net Export Share has a significant negative coefficient (as expected) for Republicans and independents, but is insignificant for Democrats. In contrast, task routineness has a larger effect on Democrats' trade policy preferences than individuals from other party affiliations. A standard deviation increase in the task routineness of one's occupation is associated with a 3.6 percentage point increase in the likelihood that a Democrat will support additional import limits, while only a 2.6 percentage point increase for individuals of other political affiliations. As shown by estimates in Table 6, differences by union affiliation are very similar to that across political affiliation. Trade policy preferences by individuals in union households are less sensitive to differences in traditional labor market attributes (particularly measures of their own skills), but more sensitive to task routineness.

Upon further investigation, the heterogeneity we find across political party or union affiliation appears to be driven by nonlinear sensitivities of trade policy 
Table 5 Political Differences in Labor Market Attributes Effects on Preferences for New Import LiMITS

\begin{tabular}{lccc}
\hline Variables & Democrat & Other & F-test for difference \\
\hline Individual skills & & & \\
Relative occupation wage & 0.033 & $\left(0.060^{*}\right.$ & 1.17 \\
& $(0.468)$ & $-0.039^{* * *}$ & $28.91^{* * *}$ \\
Education years & $-0.033^{* * *}$ & $(0.000)$ & \\
& $(0.000)$ & 0.429 & 0.76 \\
Sector trade exposure & 0.135 & $(0.237)$ & $4.60^{* *}$ \\
Sector tariff & $(0.735)$ & $-0.156^{* *}$ & \\
Sector net export share & 0.117 & $(0.048)$ & 0.53 \\
& $(0.340)$ & $0.119^{* *}$ & \\
Task routineness measure & $0.163^{* * *}$ & $(0.014)$ & \\
Routineness measure & $(0.006)$ & & \\
&
\end{tabular}

Notes: Dependent variable takes the value of " 1 " if the individual expresses support for additional import limits, and a " 0 " otherwise. All regressions include year fixed effects and other controls listed in Table 3 . $* * *, * *$, and $*$ denote statistical significance at the $1 \%, 5 \%$, and $10 \%$ levels, respectively. $p$-Values in parentheses.

Table 6 Union Membership and Differences in Labor Market Attributes Effects on Preferences FOR NEW IMPORT LIMITS

\begin{tabular}{lccc}
\hline Variables & Union & Not union & $F$-test for difference \\
\hline Individual skills & & & \\
Relative occupation wage & -0.004 & $0.070^{* *}$ & $4.32^{* *}$ \\
& $(0.539)$ & $(0.028)$ & $30.80^{* * *}$ \\
Education years & $-0.027^{* * *}$ & $-0.038^{* * *}$ & \\
Sector trade exposure & $(0.000)$ & $(0.000)$ & 0.02 \\
Sector tariff & 0.597 & 0.363 & 0.21 \\
Sector net export share & $(0.288)$ & $(0.230)$ & \\
& -0.023 & -0.060 & 0.05 \\
Task routineness measure & $(0.871)$ & $(0.454)$ & \\
Routineness measure & $0.237^{* * *}$ & $0.107^{* *}$ & $(0.016)$ \\
& $(0.000)$ & & \\
\hline
\end{tabular}

Notes: Dependent variable takes the value of " 1 " if the individual expresses support for additional import limits, and a "0" otherwise. All regressions include year fixed effects and other controls listed in Table 3. $* * *, * *$, and $*$ denote statistical significance at the $1 \%, 5 \%$, and $10 \%$ levels, respectively. $p$-Values in parentheses.

preferences to labor market attributes coupled with systematic differences of labor attributes across political party or union affiliation. In unreported results available upon request, we find that trade policy preferences for greater import protection get increasingly stronger in task routineness and increasingly weaker in education. ${ }^{9}$ These nonlinearities are driving the differences, not ideology of these groups per se.

\footnotetext{
${ }^{9} \mathrm{We}$ included squared terms for all the labor market variables to investigate possible nonlinearities. These terms were only statistically significant for the education and task routineness variables.
} 
For example, Democrats generally have lower education than the rest of the sample (12.7 years vs. 13.3 years). As a result, Democrats are less sensitive as a group to increases in education than the rest of the sample because of their lower average education, which is connected with lower trade policy sensitivity to education than higher educated workers. This is confirmed by the fact that the differences we find in Tables 5 and 6 are no longer statistically significant when we include squared terms of our labor/industry market attributes to control for nonlinearities. ${ }^{10}$ In contrast, our results on gender differences in Table 4 are robust to controlling for nonlinear relationships between labor/industry market attributes and trade policy preferences. We also find that the trade policy preferences of workers in manufacturing sectors are more affected by routineness as well, which is again due to the fact that average routineness of tasks is generally much higher in manufacturing than in other sectors.

In summary, there is heterogeneity in how labor market attributes affect trade policy preferences, shown by two general findings. First, women's trade policy preferences seem to systematically be less affected by their labor market attributes than men. Second, greater routineness of tasks has a larger impact on preferences for trade protection in populations in the sample with higher average routineness to their tasks, which includes workers who are less-educated, union members, Democrats, and in manufacturing sectors.

\section{CONCLUSION AND DISCUSSION}

This paper provides the first evidence that task routineness of an individual's occupation affects their trade policy preferences. Using U.S. survey data, we find that individuals in occupations that involve more routine tasks are significantly more likely to support new import limits, even after controlling for other (traditional) labor market and personal/ideological attributes of the individuals. A standard deviation increase in task routineness is associated with an additional 3-percentage point increase in the individuals support for trade protection.

Personal and ideological attributes have significant effects on trade policy preferences in our estimates (and in previous literature). And we also provide the first evidence that there are important interactions between an individual's personal/ ideological attributes and their labor market attributes. We find that that women's trade policy preferences do not vary as much with their labor market attributes as men; e.g., an extra year of education does not lower women's likelihood to support additional import limits as much as it does for men. We also find some differences in trade policy elasticities with respect to labor market attributes across a number of other dimensions, including political party and union affiliation. Unlike with gender differences, these differences in other dimensions are driven by nonlinear elasticities of trade policy preferences to labor market attributes. For example, we find that the trade policy preferences of workers in manufacturing sectors are more affected by

\footnotetext{
${ }^{10} \mathrm{We}$ also explore for differences across education (at least some year of college vs. high school or less) and wages (above average wages or not). We do not find any statistical differences for these splits, except to show that there is a nonlinearity in the responsiveness of trade policy preferences to education - an increase in education has particularly strong effects on trade policy preferences for the individuals who have at least some education beyond high school - which is consistent with our results when we control for nonlinearities in the education elasticity of trade policy preferences with a squared education term.
} 
routineness due to the fact that the average routineness of tasks is generally much higher in manufacturing than in other sectors.

While we have uncovered evidence that labor market attributes impact trade policy preferences, it is important to note that there is still substantial unexplained variation in individuals' trade policy preferences. The $R^{2}$ statistics in our regressions range from 0.12 to 0.13 . The $R^{2}$ of a regression that only includes traditional labor market attributes (where education is the primary variable) is around 0.06 , while a regression with only task routineness measures has an $R^{2}$ of approximately 0.04 . When we put in industry-by-occupation fixed effects, which subsume all our labor market attribute variables, but then also accounts for any other unobserved effects connected with an individual's particular industry and occupation, we achieve an $R^{2}$ of approximately 0.30 . Thus, there is clearly room for further research into the exact ways in which the labor market attributes affect trade policy preferences, but this evidence also suggests that individuals' stated trade policy preferences are significantly affected by factors other than ones related to how trade affects their own labor market outcomes.

BRUCE A. BLONIGEN

University of Oregon and NBER

JACOB MCGREW

University of Oregon

\section{REFERENCES}

Autor, D. H., L. F. Katz and M. S. Kearney, 2003, The skill content of recent technological change: an empirical exploration. Quarterly Journal of Economics 118, 1279-1333.

—_ _ - a - _ - 2006, The polarization of the U.S. labor market. American Economic Review Papers and Proceedings 96, 189-194.

Beaulieu, E. and M. Napier, 2008, Why are women more protectionist than men? Mimeo.

Blonigen, B. A., 2011, Revisiting the evidence on trade policy preferences. Journal of International Economics 85, 129-135.

Burgoon, B. A. and M. J. Hiscox, 2004, The mysterious case of female protectionism: gender bias in attitudes toward international trade. Mimeo.

Ebenstein, A., A. Harrison, A. McMillan and S. Phillips, forthcoming, Estimating the impact of trade and offshoring on american workers using the current population surveys. Review of Economics and Statistics.

Feenstra, R. C. and G. H. Hanson, 1999, The impact of outsourcing and high-technology capital on wages: estimates for the United States, 1979-1990. Quarterly Journal of Economics 114, 907-940.

Grossman, G. M. and E. Rossi-Hansberg, 2008, Trading tasks: a simple theory of offshoring. American Economic Review 98, 1978-1997.

Hummels, D., R. Jørgensen, J. R. Munch and C. Xiang, 2014, The wage effects of offshoring: evidence from danish matched worker-firm data. American Economic Review 104, 1597-1629.

Mayda, A. M. and D. Rodrik, 2005, Why are some individuals (and countries) more protectionist than others? European Economic Review 49, 1393-1430.

O'Rourke, K. H. and R. Sinnott, 2001, The determinants of individual trade policy preferences: international survey evidence. Brookings Trade Forum, 157-206.

Scheve, K. F. and M. J. Slaughter, 2001, What determines trade policy preferences? Journal of International Economics 54, 267-292. 